Підлипна Р. П., radmila2008@ukr.net, ORCID ID: 0000-0001-6886-5834, д. е. н., проф., завідувач кафедри фінансів, Ужгородський торговельно-економічний інститут Київського національного торговельно-економічного університету, м. Ужгород

\title{
ОЦІНЮВАННЯ ІНВЕСТУВАННЯ В СОЦІАЛЬНО-ЕКОНОМІЧНИЙ РОЗВИТОК ПЕРСОНАЛУ ПІДПРИЕМСТВА
}

\begin{abstract}
Анотація. Статтю присвячено методологічним аспектам оцінювання економічної доцільності інвестицій y сочіально-економічний розвиток персоналу, яка визначається високим рівнем їх окупності і потребує оптимізації інвестиційних потоків підприємства. Визначено, щчо загальними ицілями розвитку персоналу є створення умов для стимулювання розкриття потенціалу працівників $і$ забезпечення високої вмотивованості щзодо досягнення поставлених завдань. Показано, щчо особливістю сучасних підходів до розвитку персоналу є завдання творчої імплементації у реальну комериійну практику існуючих та безперервної генерації нових знань. Зміни в економічних системах постіндустріального етапу ставлять до персоналу вимоги знання інноваційних технологій, здатності розробляти та впроваджувати нові проекти. Водночас сочіальна позиція визначає місие працівника в системі управлінських відносин, залежить від його функиіональних обов'язків $і$ професійнокваліфікаційної характеристики. Ефективне інвестування у соиіально-економічний розвиток передбачає витрати на навчання, охорону здоров'я, виховання і підвищення лояльності працівників до підприємства. Однак кадрова політика більшості підприємств наџілена виключно на зменшення витрат, а система мотивації зводиться до процедури оплати праці. Оџінювання потреби в розвитку персоналу є підгрунтям виявлення причинно-наслідкового зв'язку між запланованими навчальними програмами і набутим у результаті їх реалізації соціально-економічним ефектом, щзо дозволяє включати планування розвитку персоналу в загальну стратегію розвитку підприємства. Запропонований поетапний алгоритм аналізу дозволяє як точно $i$ неупереджено врахувати загальну ефективність інвестицій у сочіально-економічний розвиток персоналу, так $і$ об'єктивно оцінити кожну зі складових проекту на відповідність иілям розвитку підприємства і окремих працівників. Подальші дослідження пропонується спрямувати на аналіз впливу окремих напрямків сочіально-економічного розвитку на рівень забезпечення сочіальної безпеки підприємства.
\end{abstract}

Ключові слова: інвестиції, економічний ефект, кадрова політика, соціальна позиція, мотивація, знання.

Pidlypna R. P., radmila2008@ukr.net, ORCIDID:0000-0001-6886-5834,

Doctor of Economics, Professor, Head of the Department of Finance, Uzhgorod Institute of Trade and Economics of Kyiv National University of Trade and Economics, Uzhgorod

\section{EVALUATION OF INVESTMENT IN SOCIO-ECONOMIC DEVELOPMENT OF ENTERPRISE STAFF}

\begin{abstract}
The article is devoted to the methodological aspects of assessing the economic feasibility of investment in socio-economic development of staff, which is determined by the high level of their payback and requires optimization of investment flows of the enterprise. It is determined that the general goals of staff development are to create conditions to stimulate the disclosure of the potential of employees and ensure their high motivation to achieve the objectives. It is shown that the peculiarity of modern approaches to staff development is the task of creative implementation in real commercial practice of existing and continuous generation of new knowledge. Changes in the economic systems of the post-industrial stage require staff with knowledge of innovative technologies as well as the ability to develop and implement new projects. At the same time, the social position determines the place of the employee in the system of managerial relations, depends on his functional responsibilities and professional qualifications. Effective investment in socio-economic development involves spending on training, health care, education and increasing employee loyalty to the company. However, the personnel policy of most companies is aimed exclusively at reducing costs, and the system of motivation is reduced to the procedure of remuneration. Assessing the need for staff development is the basis for identifying the causal link between the planned training programs and the resulting socio-economic effect, which allows to include staff development planning in the overall development strategy of the enterprise. The proposed step-by-step analysis algorithm allows to accurately and impartially take into account both the overall efficiency of investment in socio-economic development of staff, and objectively assess each of the components of the project to meet the development goals of the enterprise and individual employees. Further research is proposed to focus on the analysis of the impact of certain areas of socio-economic development on the level of social security of the enterprise.
\end{abstract}

Keywords: investments, economic effect, personnel policy, social position, motivation, knowledge.

JEL Classification: J24, J31, M14, M53

DOI: https://doi.org/10.36477/2522-1205-2021-63-10 


\section{Herald of Lviv University of Trade and Economics. Economic Sciences. № 63, 2021}

Постановка проблеми. Розвиток персоналу $є$ складним економічним процесом, управління яким має забезпечувати не лише надбання працівниками нових знань і когнітивних навичок, але і високу соціально-економічну та комерційну віддачу капіталовкладень у людські ресурси. За влучною оцінкою С. Нісфоян, управління витратами на розвиток персоналу має принципово безперервний характер, оскільки знаходиться під тиском низки зовнішніх та внутрішніх чинників змінного характеру впливу [8, с. 61]. Своєю чергою, інвестиції у розвиток персоналу можуть вважатись економічно доцільними лише за умови високого рівня їх окупності. Отож, оптимізація інвестиційних потоків підприємства для досягнення економічної ефективності програм внутрішньофірмового навчання $\epsilon$ актуальною проблемою управління соціальноекономічним розвитком персоналу.

Аналіз останніх досліджень і публікацій. У питаннях соціально-економічного розвитку персоналу більшість дослідників схиляється до виокремлення його в якості основного ресурсу підприємств. Так, К. Булана, Л. Шимановська-Діанич розглядають управління соціальним розвитком підприємства як створення сприятливих умов праці, побуту i відпочинку персоналу, його матеріальне і моральне винагородження, соціальний захист, формування i підтримку здорової морально-психологічної атмосфери, забезпечення ділового співробітництва i соціального партнерства [4]. С. Бірбіренко та С. Мацан наголошують, що стійка конкурентоспроможність підприємств напряму залежить від ефективності сформованої стратегії управління людськими ресурсами [3]. Водночас автори підкреслюють, що успішна стратегія розвитку персоналу потребує диференційованого підходу 3 урахуванням соціальних ролей працівників та їх вкладу в процеси створення споживчих цінностей. I. Сочинська-Сибірцева оцінює розвиток персоналу 3 точки зору потенціалу зростання конкурентоспроможності [10]. Автор доводить нагальність впровадження нових технологій управління персоналом, які дозволять якісно змінити, істотно вдосконалити і стандартизувати процедури професійного розвитку і забезпечити оперативний моніторинг їх надійності.

Ю. Залознова, досліджуючи взаємозв'язок управління розвитком персоналу 3 соціальною відповідальністю бізнесу, виокремлює питання забезпечення комфортності праці, компетентності працівників, їх соціальної захищеності як факторів, що створюють конкурентні переваги в результативності праці персоналу, позитивну оцінку результатів діяльності у суспільній свідомості [6]. O. Байрачна запропонувала структуру механізму функціонального забезпечення ефективності розвитку персоналу, в межах якого чітко визначила цілі, завдання та інструменти, а також виділила етапи формування механізму функціональної підготовки працівників [1]. Т. Білорус та А. Філіна вивчали можливості адаптації методичного інструментарію оцінки та перегляду планів під час оптимізації програми розвитку персоналу підприємства в умовах нечіткої та неповної інформації [2].

Разом 3 тим, практично не вирішеними на сьогодні залишаються питання ефективності інвестування у розвиток персоналу. Зокрема, лише у дослідженні Л. Янковської та ін. підкреслюється важливість такого аналізу для адекватності прийняття рішень щодо обсягів інвестицій [11]. Отож, можна стверджувати також про відсутність напрацювань методологічного спрямування щодо процедури економічної оцінки ефективності інвестування соціально-економічного розвитку персоналу.

Постановка завдання. Метою даного дослідження $є$ розроблення методичного інструментарію для адекватного оцінювання фінансової ефективності інвестицій у соціально-економічний розвиток персоналу у відповідності до цілей розвитку підприємства і працівників.

Виклад основного матеріалу дослідження. Трансформаційні перетворення світового глобалізованого суспільства висувають беззаперечні вимоги до успішного та конкурентного економічного розвитку господарюючих суб'єктів, що передбачають всебічне використання новітніх науковотехнологічних досягнень та високопродуктивних методів управління. Управління соціальноекономічним розвитком персоналу дозволяє забезпечувати підприємство працівниками, здатними завдяки власним виробничим компетенціям i навичкам повністю реалізувати корпоративну стратегію. Загальними цілями розвитку персоналу $є$ створення умов для стимулювання розкриття потенціалу працівників і забезпечення високої вмотивованості щодо досягнення поставлених завдань. Визначальною особливістю сучасних підходів до розвитку персоналу $є$ завдання творчої імплементації у реальну комерційну практику існуючих та безперервної генерації нових знань.

Успішність соціально-економічного розвитку персоналу значною мірою визначається набутими працівниками соціальними позиціями і соціальними ролями. Соціальна позиція визначає місце працівника в системі управлінських відносин, залежить від його функціональних обов'язків і професійно-кваліфікаційної характеристики. Соціальна позиція зумовлює сенсове наповнення соціальної ролі, відповідаючи на запитання, що має робити даний працівник. Отож, соціальна роль може розглядатися як певний набір соціальних функцій та стандартів діяльності і поведінки, що реалізується відповідно до соціальної позиції. Зміст соціальних ролей працівників визначається специфічними соціальними експектаціями, що зумовлюються як безпосередньо організаційно-технологічним наповненням їх діяльності, так і соціальними вимогами у конкретні періоди суспільного розвитку. Зокрема, зміни в економічних системах постіндустріального 
етапу розвитку потребують знання персоналом підприємств інноваційних технологій, здатності розробляти та впроваджувати нові проекти, схильності до наукової та маркетингової діяльності, володіння іноземними мовами, навичок ділових переговорів тощо.

Соціально-економічна ефективність управління розвитком персоналу передбачає опанування нових знань і якісне підвищення кваліфікаційних характеристик працівників [9]. Сучасна концепція управління соціально-економічним розвитком персоналу сформувалася як фактор підвищення конкурентоспроможності підприємства. Інвестиції у соціальноекономічний розвиток передбачають витрати на навчання, охорону здоров'я, виховання і підвищення лояльності працівників до підприємства. Однак на практиці кадрова політика більшості підприємств, особливо малого і серед-нього бізнесу, націлена виключно на зменшення витрат на утримання персоналу, спираючись лише на інструменти суміщення посад, делегування та перерозподілу повноважень. Функції управління розвитком персоналу обмежуються найчастіше адміністративними процедурами та контролінгом, а система мотивації зводиться лише до процедури оплати праці.

Забезпечення професійно-кваліфікаційного розвитку кадрів зазвичай грунтується на конкурентній стратегії та прогнозних розрахунках фінансових можливостей підприємства. Разом з тим, соціальноекономічна ефективність передбачає наявність не лише кількісних, але і якісних ефектів розвитку персоналу (табл. 1). Зважаючи на необхідність зростання ефективності соціального і професійного розвитку працівників, безумовно важливими $\epsilon$ адаптивні управлінські заходи, спрямовані на розкриття інформації щодо місії та стратегії підприємства, його виробничої (товарної) спеціалізації, стратегічних орієнтирів.
Виходячи 3 того, що загальною стратегічною метою функціонування підприємства як виробничо-господарської структури $є$ зростання його капіталізації [7], саме динаміка економічної результативності розвитку персоналу має покладатися в основу дослідження ефективності відповідних інвестицій. Загальне поняття комерційної ефективності соціально-економічного розвитку грунтується на співвідношенні доходів і витрат, отож, іiї зростання можна описати як функцію, обмежену умовами максимізації ефекту і мінімізації капіталовкладень. Такий підхід передбачає певну етапізацію аналізу ефективності:

1) ідентифікація та вартісна оцінка отриманих ефектів за певний період часу;

2) ідентифікація та вартісна оцінка здійснених витрат за аналогічний період часу;

3) порівняння отриманих на попередніх етапах оцінок.

Оскільки особливістю інвестування в розвиток персоналу $є$ розбіжність у термінах капіталовкладень і отриманих ефектів [5], постає завдання зведення грошових потоків до єдиного часового проміжку. На нашу думку, в даному випадку варто скористатись інструментами дисконтування, адже в підгрунті цього методу закладено процедуру визначення еквівалентної вартості капіталу в різні часові проміжки. Отож, завдання приведення вартості майбутніх доходів до теперішнього часового періоду зводиться до введення у розрахунки відповідного коефіцієнта дисконтування:

$$
k=\frac{1}{(1+r)^{t}},
$$

де $k$ - коефіцієнт дисконтування; $r$ - норма дохідності (дохідність альтернативних інвестицій 3 аналогічним або незначно меншим рівнем ризиковості і термінами реалізації); $t$ - період часу.

Таблиия 1

Класифікація соціально-економічних ефектів інвестування у розвиток персоналу підприсмства

\begin{tabular}{|c|c|}
\hline Економічні ефекти & Соціальні ефекти \\
\hline $\begin{array}{ll}\text { - } & \text { збільшення обсягів виробництва; } \\
\text { - } & \text { зростання товарообороту; } \\
\text { - } & \text { зростання капіталізації (прибутковості); } \\
\text { - } & \text { збільшення частки ринку; } \\
\text { - } & \text { зростання продуктивності праці; } \\
\text { - } & \text { зменшення плинності кадрів; } \\
\text { - } & \text { скорочення термінів заповнення вакансій; } \\
\text { - } & \text { зростання кількості інноваційних пропозицій; } \\
\text { - } & \text { зростання кількості запроваджених інновацій. }\end{array}$ & $\begin{array}{ll}\text { - } & \text { зростання якості роботи персоналу; } \\
\text { - } & \text { покращення психологічного клімату в колективі; } \\
\text { - } & \text { зміцнення виробничої дисципліни; } \\
\text { - } & \text { розвиток мотиваційних програм; } \\
\text { - } & \text { розвиток корпоративної культури; } \\
\text { - } & \text { зростання прихильності споживачів; } \\
\text { - } & \text { посилення іміджевих позицій підприємства. }\end{array}$ \\
\hline
\end{tabular}

Джерело: розроблено автором 
Приклад критеріїв для визначення відповідності отриманих ефектів цілям соціально-економічного розвитку персоналу

\begin{tabular}{|l|c|}
\hline \multicolumn{1}{|c|}{ Можливий критерій } & Вага \\
\hline Рівень зростання капіталізації & 0,3 \\
\hline Рівень зростання продуктивності праці & 0,25 \\
\hline Генерація інноваційних ідей, корисних для підприємства & 0,2 \\
\hline Досягнення позитивного психологічного клімату & 0,15 \\
\hline Рівень задоволення мотиваційних експектацій персоналу & 0,1 \\
\hline \multicolumn{2}{|c|}{ Разом } \\
\hline
\end{tabular}

Джерело: розроблено автором

Вирішення проблеми адекватного оцінювання фінансової ефективності інвестицій у соціальноекономічний розвиток персоналу може лежати в площині адаптації методики ROI (Return on Investments), запропонованої J. Phillips для оцінювання рентабельності інвестицій [12, с. 33-59]. Релевантні показники для оцінювання ефектів розвитку персоналу доцільно виділяти вже на етапі розроблення проекту, а зафіксовані зміни оцінювати у грошовому еквіваленті, акумулюючи їх в показнику дохідності:

$$
R O I=\frac{Д-B}{B} \cdot 100 \%,
$$

де Д - дохідність проекту; $B$ - витрати на реалізацію проекту.

Разом 3 тим, цілком очевидною $є$ складність практичного застосування даної методики в більшості підприємств через іiі багатофакторність i значну ресурсомісткість акумулювання отриманих ефектів у загальний показник дохідності проекту. До того ж, такий алгоритм повністю виключає 3 аналізу етап оцінювання потреб у розробці проектів розвитку персоналу. Це спонукало нас до пошуку шляхів вирішення означеної проблеми.

Ми виходили 3 того, що оцінювання потреби підприємства в розвитку персоналу є підгрунтям подальшого виявлення причинно-наслідкового зв'язку між запланованими навчальними програмами і набутим у результаті їх реалізації соціальноекономічним ефектом, що дозволяє включати планування розвитку персоналу в загальну стратегію розвитку підприємства. На наше переконання, об'єктивність такого аналізу забезпечується включенням різних рівнів ієрархії: на рівні підприємства (узгодження проекту із загальною стратегією), окремого робочого місця (визначення необхідних компетенцій) та окремих працівників (з'ясування міри відповідності знань і професійних навичок посаді працівника).

Для оцінювання рівня відповідності отриманих ефектів розвитку персоналу визначеним загальноорганізаційним цілям доцільно сформувати оціночні критерії, важливість (вага) яких для загальних цілей розвитку підприємства визначатиметься його керівниками експертним шляхом (табл. 2). Зазначимо, що наведені у таблиці критерії не є конкретизованими 3 міркувань забезпечення узагальненої схеми оцінювання. Разом 3 тим, для практичного застосування запропонованої методики підприємствам варто розробляти власні критерії досягнення позитивного ефекту розвитку персоналу, які би узгоджувалися з корпоративною стратегією.

Отож, коефіцієнт відповідності отриманих ефектів $\left(k_{\text {вidn }}\right)$ цілям розвитку персоналу має повною мірою відображати рівень виконання поставлених до проекту розвитку вимог:

$$
k_{\text {вidn }}=\frac{\sum_{i=1}^{n} l_{i} w_{i}}{\sum_{i=1}^{n} w_{i} b_{i}}
$$

де $l_{i}$ - оцінка досягнутого ефекту за $i$-им критерієм; $w_{i}$ - вага $i$-го критерію; $b_{i}$ - максимально можлива оцінка за $i$-им критерієм, $n$ - кількість критеріїв.

Для аналізу економічного ефекту інвестування в проект розвитку персоналу важливо підібрати такі критерії оцінювання, які би повною мірою відображали залежність зростання капіталізації підприємства від отриманих ефектів. Отож, показник чистої дисконтованої вартості пропонуємо скорегувати на отриманий на попередньому етапі коефіцієнт відповідності.

$$
\begin{aligned}
& N P V=\sum_{t=0}^{n} \frac{\Gamma \Pi b x_{t}-\Gamma \Pi b u x_{t}}{(1+r)^{t}} \cdot k_{\text {вidn }} \\
& \text { де } \Gamma \Pi в x_{t}-\text { вхідні грошові потоки; }
\end{aligned}
$$

IIвux $t_{t}$ - вихідні грошові потоки; $r$ - норма дохідності (дохідність альтернативних інвестицій 3 аналогічним або незначно меншим рівнем ризиковості i термінами реалізаціі); $k_{\text {вiдn }}-$ коефіцієнт відповідності отриманих ефектів; $t$ - номер періоду часу, в якому було забезпечено повну окупність інвестицій.

Ефективність інвестування в соціальноекономічний розвиток персоналу залежить також від впровадження мотиваційних програм, спрямованих на стимулювання безперервного навчання $\mathrm{i}$ самовдосконалення працівників. 
Висновки i перспективи подальших досліджень у даному напрямі. Аналіз ефективності проекту соціально-економічного розвитку персоналу є надзвичайно важливим для забезпечення зростання капіталізації підприємства. Залучення елементів оцінювання на етапі підготовки проекту дозволяє узгодити його з основними стратегічними цілями підприємства, вчасно виявити можливі розбіжності і скорегувати певні елементи проекту розвитку. Запропонований поетапний алгоритм такого аналізу дозволяє як точно і неупереджено врахувати загальну ефективність інвестицій в соціально-економічний розвиток персоналу, так і об'єктивно оцінити кожну зі складових проекту на відповідність цілям розвитку підприємства і окремих працівників. Подальші дослідження у царині ефективності інвестування у соціальноекономічний розвиток персоналу варто спрямувати у бік аналізу впливу окремих напрямків соціальноекономічного розвитку на рівень забезпечення соціальної безпеки підприємства.

\section{ЛІТЕРАТУРА}

1. Байрачна О. К. Архітектоніка механізму функціональної підготовки управлінського персоналу в системі менеджменту підприємства / Байрачна О. К. // Восточно Европейский Научный Журнал. - 2020. - № 1(11). - С. 4-8.

2. Білорус Т. В. Оптимізація програми розвитку персоналу підприємства / Білорус Т. В., Філіна А. Р. // Вісник Одеського національного університету. Серія: Економіка. - 2018. - № 23. C. 47-51.

3. Бірбіренко С. С. Стратегія управління персоналом підприємства у сучасних ринкових умовах / Бірбіренко С. С., Мацан Т. М. // Економічний вісник Запорізької державної інженерної академії. 2018. - № 5. - C. 62-65.

4. Булана К. В. Впровадження соціальних програм розвитку на ДП "НАЕК “Енергоатом" в умовах трансформації національної економіки України / Булана К. В., Шимановська-Діанич Л. М. // Економіка, фінанси та менеджмент: сучасний стан, тенденції, перспективи розвитку в Україні та світі : Збірник тез доповідей Міжнародної науковопрактичної конференції (Полтава, 29 січня 2018 р.). Полтава : ЦФЕНД, 2018. С. 83-84.

5. Дзямулич М. I. Управління розвитком персоналу підприємства в умовах економічної глобалізації / Дзямулич М. І., Шматковська Т. О. // Економічний форум. - 2020. - № 1(3). - С. 138-142.

6. Залознова Ю. С. Пріоритетні напрями розвитку персоналу підприємств на засадах соціальної відповідальності як інструменту досягнення сталого розвитку / Залознова Ю. С. // Вісник Кам'янець-Подільського національного університету імені Івана Огієнка. - 2017. Вип. 12(1). - С. 194-201.

7. Ковальська К. В. Організаційно-методичні аспекти реалізації стратегії розвитку персоналу підприємства / Ковальська К. В., СолодаренкоЛітковська Р. А. // Економіка та держава. - 2020. № 7. - C. 150-154.

8. Нісфоян С. С. Управління витратами на утримання і розвиток персоналу підприємств : монографія / Нісфоян С. С. - Кропивницький : Лисенко, 2020. - 268 c.

9. Савченко В. А. Фінансування професійного навчання персоналу на виробництві в Україні / Савченко В. А., Гемма М. Д. // Соціально-трудові відносини: теорія і практика. - 2016. - Вип. 1. C. $42-51$.

10. Сочинська-Сибірцева I. М. Надійність персоналу як соціально-економічний важіль забезпечення конкурентоспроможності підприємства / Сочинська-Сибірцева I. М. // Конкурентоспроможна модель інноваційного розвитку економіки України : збірник тез доповідей Міжнародної науково-практичної конференції (Кропивницький, 11 квітня 2018 р.). -Кропивницький : ЕксклюзивСистем, 2018. - С. 187-189.

11. Система інвестування розвитку персоналу: вигоди, ризики, ефективність корпоративної культури / Янковська Л. А., Бочко О. Ю., Скупейко В. В., Хілуха О. А. // Наукові записки Львівського університету бізнесу та права. - 2020. - № 25. C. 126-132.

12. Phillips J. J. Return on Investment in Training and Performance Improvement Programs. 2nd ed., Burlington, MA: Butterworth-Heinemann, 2003. 414 p.

\section{REFERENCES}

1. Bajrachna, O. K. (2020), Arkhitektonika mekhanizmu funktsional'noi pidhotovky upravlins'koho personalu v systemi menedzhmentu pidpryiemstva, Vostochno Evropejskyj Nauchnyj Zhurnal, № 1(11), s. 4-8.

2. Bilorus, T. V. and Filina, A. R. (2018), Optymizatsiia prohramy rozvytku personalu pidpryiemstva, Visnyk Odes'koho natsional'noho universytetu. Seriia: Ekonomika, № 23, s. 47-51.

3. Birbirenko, S. S. and Matsan, T. M. (2018), Stratehiia upravlinnia personalom pidpryiemstva $\mathrm{u}$ suchasnykh rynkovykh umovakh, Ekonomichnyj visnyk Zaporiz'koi derzhavnoi inzhenernoi akademii, № 5, s. $62-65$.

4. Bulana, K. V. and Shymanovs'ka-Dianych, L. M. (2018), Vprovadzhennia sotsial'nykh prohram rozvytku na DP "NAEK "Enerhoatom" v umovakh transformatsii natsional'noi ekonomiky Ukrainy, Ekonomika, finansy ta menedzhment: suchasnyj stan, tendentsii, perspektyvy rozvytku $v$ Ukraini ta sviti : Zbirnyk tez dopovidej Mizhnarodnoi naukovopraktychnoi konferentsii (Poltava, 29 sichnia 2018 r.), TsFEND, Poltava, s. 83-84.

5. Dziamulych, M. I. and Shmatkovs'ka, T. O. (2020), Upravlinnia rozvytkom personalu pidpryiemstva $\mathrm{v}$ umovakh ekonomichnoi hlobalizatsii, Ekonomichnyj forum, № 1(3), s. 138-142.

6. Zaloznova, Yu. S. (2017), Priorytetni napriamy rozvytku personalu pidpryiemstv na zasadakh 
sotsial'noi vidpovidal'nosti iak instrumentu dosiahnennia staloho rozvytku, Visnyk Kam'ianets'-Podil's'koho natsional'noho universytetu imeni Ivana Ohiienka, vyp. 12(1), s. 194-201.

7. Koval's'ka, K. V. and Solodarenko-Litkovs'ka, R. A. (2020), Orhanizatsijno-metodychni aspekty realizatsii stratehii rozvytku personalu pidpryiemstva, Ekonomika ta derzhava, № 7, s. 150-154.

8. Nisfoian, S. S. (2020), Upravlinnia vytratamy na utrymannia i rozvytok personalu pidpryiemstv : monohrafiia, Lysenko, Kropyvnyts'kyj, 268 s.

9. Savchenko, V. A. and Hemma, M. D. (2016), Finansuvannia profesijnoho navchannia personalu na vyrobnytstvi v Ukraini, Sotsial'no-trudovi vidnosyny: teoriia i praktyka, vyp. 1, s. 42-51.

10. Sochyns'ka-Sybirtseva, I. M. (2018), Nadijnist' personalu iak sotsial'no-ekonomichnyj vazhil' zabezpechennia konkurentospromozhnosti pidpry- iemstva, Konkurentospromozhna model' innovatsijnoho rozvytku ekonomiky Ukrainy : zbirnyk tez dopovidej Mizhnarodnoi naukovo-praktychnoi konferentsii (Kropyvnyts'kyj, 11 kvitnia 2018 r.), Ekskliuzyv-System, Kropyvnyts'kyj, s. 187-189.

11. Yankovs'ka, L. A. Bochko, O. Yu. Skupejko, V. V. and Khilukha, O. A. (2020), Systema investuvannia rozvytku personalu: vyhody, ryzyky, efektyvnist' korporatyvnoi kul'tury, Naukovi zapysky L'vivs'koho universytetu biznesu ta prava, № 25, s. 126-132.

12. Phillips, J. J. (2003), Return on Investment in Training and Performance Improvement Programs, 2nd ed., Burlington, MA: Butterworth-Heinemann, 414 r.

Стаття надійшла до редакції 03 травня 2021 року 